\title{
Health Check-up of the Commercial Banks in Bangladesh: An Application of CAMELS Model
}

\author{
Rozina Akter \\ Department of Business Administration, Faculty of Business and Economics, Daffodil International University, Dhaka, Bangladesh \\ Email address: \\ rozina@daffodilvarsity.edu.bd

\section{To cite this article:} \\ Rozina Akter. Health Check-up of the Commercial Banks in Bangladesh: An Application of CAMELS Model. International Journal of \\ Business and Economics Research. Vol. 5, No. 2, 2016, pp. 19-28. doi: 10.11648/j.ijber.20160502.11
}

Received: December 30, 2015; Accepted: January 18, 2016; Published: March 12, 2016

\begin{abstract}
Banking sector is the most important component of financial system. Development of banking system contributes to the stability and sustainable economic growth. This is one of the Major Service sectors in Bangladesh economy, which divided into four categories of scheduled Banks. These are Nationalized Commercial Banks (NCBs), Government Owned Development Financial Institutions (DFIs), Private Commercial Banks (PCBs), and Foreign Commercial Banks (FCBs). The aim of the research is to comparatively analyze the financial soundness of the commercial banks that operate in Bangladesh. In order to achieve this we have used one of the most popular methods for the analysis of the financial soundness of banks, namely the CAMELS framework. At present, a total of 56 banks (4 SCBs, 4 DFIs, 39 PCBs and 9 FCBs) having 8794 branches are operating in Bangladesh with Tk. 8675.2 billion total assets and Tk. 6558.7 billion deposits. Quantitative comparison has been done on the basis of CAMEL ratio. CAMEL ratios mainly indicate the adequacy of the risk based capital, non-performing loan position, expenditure-income ratio, return on assets (ROA), return on equity (ROE), net interest income (NII), writing of debt, liquid assets, excess liquidity, etc. The study compares the 4 types of bank's time series performance on the basis of selected CAMEL ratios. CAMELS rating system shows that no banks have been rated 1 or Strong; the rating of 28 banks were 2 or satisfactory; rating of 12 banks were 3 or fair; 6 banks were rated 4 or marginal and 1 bank received 5 or unsatisfactory rating.
\end{abstract}

Keywords: Capital Adequacy, Asset Quality, Management Efficiency, Earnings, Liquidity, Sensitivity to Market Risk, RoA, ROE, NPL, NIM

\section{Introduction}

The banking sector of Bangladesh comprises four categories of scheduled banks. These are State-owned Commercial Banks (SCBs), State-owned Development Financial Institutions (DFIs), Private Commercial Banks (PCBs) and Foreign Commercial Banks (FCBs). Nine (9) newly licensed private commercial banks have started functioning in this year. So the number of banks increased from 47 in 2012 to 56 in 2013. These banks had a total number of 8685 branches as of December 2013. The number of bank branches increased from8322 of 2012 to 8685 due to opening of new branches mainly by the PCBs, DFIs and SCBs during the year. At the end of June 2014, the total number of bank branches increased further to 8794 , with total number of banks remained unchanged at 56. In order to ensure a healthy, solid and stable banking sector, the banks must be analyzed and evaluated in a way that will allow the smooth correction and removal of the potential vulnerabilities. In this way, one of the most popular methods for the analysis and evaluation of the banks soundness is represented by the CAMELS framework. The aim of the research is to analyze the financial soundness of the commercial banks that operate in Bangladesh. In order to achieve this aim our methodology is based on the CAMELS framework. Since a regulator, Bangladesh Bank has statutory task to assess the overall strength of the banking companies and the non-financial institutions. A uniform rating system for all banking companies and non-financial institutions are used to help the stakeholders. The rating system will provide significant and concise information about the condition of the banking system, as well as identify those banking companies and non-financial institutions. Now especially I think our 
banking sector is a major industry in our emerging economy. We should look after and nursing very carefully this sector which may be developed and expanded its activities in all respect. Very virtually it is said that the economy of a country depends on its banking system. As banking system be healthy, as well as country's economy be healthy and wealthy. So banking system should monitor very cautiously. The assessing instrument is CAMELS; that is the key area of a banking company.

\section{Literature Review}

Various studies relating to the financial performance of banks have been conducted by researchers. Sanni (2009) took a look at the 2005 consolidation of banks exercise in Nigeria with a view of finding out the short term effect of increase in the minimum paid-up capital of banks on their performance. After an examination of thirteen banks, Sanni had a mixed result for his selected banks. K. V. N. Prasad and A. A. Chari (2011) conducted a study to evaluate financial performance of public and private sector banks in India. In this study they compared financial performance of top four banks in India viz., SBI, PNB, ICICI and HDFC and concluded that on overall basis HDFC rated top most position. Nimalathasan B. (2008) highlighted comparison of financial performance of banking sector in Bangladesh using CAMELS rating system. Accordingly CAMELS rating system shows that 3 banks was 01 or Strong, 31 banks were rated 02 or Satisfactory, rating of 7 banks was 03 or Fair, 5 banks were rated 4 or Marginal and 2 banks got 05 or Unsatisfactorily rating. $1 \mathrm{NCB}$ had Unsatisfactorily rating and other $3 \mathrm{NCBs}$ had Marginal rating. Based on the above literature, we can say that there are some studies about banks in various countries; however a detailed study (through the CAMEL rating system) has not yet been conducted for post-2005 bank consolidation in Nigeria. Hence the present study is made on "A Comparative Performance Evaluation of the Nigerian Banking Sector in the Post - 2005 Consolidation: Through the CAMEL Rating System" using all the 15 quoted banks on the Nigerian Stock Exchange as at April, 2012. Demirgüc-Kunt and Huizinga (1999) studied 80 countries in the years 1988-1995 and they reported that banks which have higher capital intensity also have greater return margin and banks are less profitable in the countries where sector intensity is very high. Their research revealed that the banks with foreign capital are more profitable in the developing countries and there is a positive relationship between inflation and profitability. The same researchers (2000) proved in the other study that the bank profitability is less in the countries where the development of stock markets is weak. Naceur (2003) examined the impact of bank's characteristics, financial structure and macroeconomic indicators on bank's net interest margins and profitability in the Tunisian banking industry for 1980-2000 period. Researcher found that while macroeconomic indicators, such as inflation and growth rate have no impact on net interest margin and profitability of Tunisian banks, stock market development has a positive effect on bank profitability and size has mostly negative effect on the net interest margins. Taşkın (2011) analyzed the macroeconomic and bank specific determinants of bank performance in Turkish banking industry for 1995-2009 period. Performance factors used in this study were return on assets, return on equity and net interest margin. Findings obtained from the study shown that bank performance is mostly affected by bank-specific factors, but macroeconomic factors do not have statistically significant effects on the performance. 2001 crisis lived in Turkey has negative effect on the performance of the banking system. Tan and Floros (2012) evaluated the determinants of bank profitability in China using the data of 101 banks in the years 2003-2009 by means of two step generalized methods of moments (GMM) estimators. Empirical results exhibited that there is a positive relationship between bank profitability, cost efficiency, banking sector development, stock market development and inflation in China. The authors reported that low profitability can be explained by higher volume of non-traditional activity and higher taxation and confirmed that there is a competitive environment in the Chinese banking industry. Safarli and Gumush (2012) in their paper used CAMELS performance rating system and panel data analysis for examining the relationship between performance of Azerbaijan banking system and macroeconomic factors in the period of 20032008. Their empirical results indicated that performance of banks decreased from 2005 to 2008, and inflation and GDP are negative related with performance of banking system. Thagunna and Poudel (2013) developed a performance model for measuring relative efficiency and potential improvement capabilities of Nepali Banks. They used data envelopment analysis (DEA) in period of 2007-08 and 201011. They found that both the ownership type and the asset size of a bank don't affect its efficiency. Obeidat et al (2013) analyzed the most important internal and external variables that contributed toward the profitability of the Islamic banks in Jordan over the period 1997- 2006 employing robust for various regression models. Findings obtained from the study shown that the most important internal determinants of profitability are total deposit, cost of deposits, total expenditures, Mudaraba loans and restricted investment deposits, the main external determinants are the money supply and market share. Baltacı (2014) investigated the relationship between the profitability of Turkish banks in the sector and macro-economic variables using the sectorial data of 31 banks in period of 2001-2011. As a result of his analysis, a positive relationship between bank profitability, inflation and indicators of crisis has been found. Helhel and Varshalomidze (2014) used CAMELS rating system to evaluate the performance and efficiency of the Georgian banking sector. In this study, six domestic private commercial banks for the period 2007 to 2013 were analyzed using eighteen financial ratios. It was emerged that after the war with Russia and economic crises during 2008-2009 period, none of the banks involved in this research could obtain an improvement in terms of each component and provide an improvement in their performance. Gaytán and Johnson 
(2002) argued that this model is highly compatible for the assessment of the performance of the bank. Sarker (2005) found that CAMELS methodology was adopted by North America Bank regulators to judge the financial and managerial reliability of commercial lending institutions. This model assesses the overall condition of the bank, its strengths and weaknesses. Wirnkar and Tanko (2008) emphasized the importance of CAMEL model in examining the overall performance of bank. The study highlighted the importance of each component in CAMEL and evaluated the best ratios that bank regulators can adopt in assessing the efficiency of banks. Dahiyat (2012) examined each parameter of CAMELS system (Capital adequacy, asset quality, management quality, earning, liquidity and sensitivity to market risks) by conducting literatures and empirical studies, and relying on interviews with responsible persons in Jordan securities commission and brokerage firms. Barr et al. (2002) described the CAMELS rating system used by bank examiners and regulators; and finds that banks with high efficiency scores also have strong CAMELS ratings. Bodla and Verma (2006) attempted CAMEL rating system to analyze the problems faced by the banks and analyzed the comparative analysis of the performance of various banks. Grier (2007) recommended that management is considered to be the single most important element in the CAMEL rating system because it plays a significant role in bank's success. Muhammad (2009) in his study claimed that the strength of CAMEL's factor is responsible for the overall strength of the bank. In an empirical study Bernanke (2007) observed that U. S. Federal Reserve investigated the safety and soundness of financial stability in banks through the on-site bank examination with the support of the CAMEL rating model. Veni (2004) highlighted the importance of capital adequacy requirement and the measures adopted by banks to build up their capital ratios. The study highlighted that the rating agencies using CAMEL model emphasized on capital adequacy ratios of banks in order to rate the bank's certificate of deposits, fixed deposits and bonds. Gupta and Kaur (2008) in their study used CAMEL model for the assessment of the performance of Indian private sector banks and ranked the top five and bottom five banks. Accordng to Deyoung et all, "The CAMELS focuses on the evaluation of performance of the financial institutions by examining its balance sheet, as well as, profit and loss statement on the basis of each components, thus observing the institution's dynamic aspect" [Deyoung et all, 2001].

\section{Objectives of the Study}

- To study the category wise performance of all scheduled banks operating in Bangladesh on the basis of selected CAMELS ratio.

- To rank the banks in terms of performance on the basis of analysis of CAMELS ratios.

- to suggest measures, on the basis of the study results, to improve further the financial performance of the banks under study

\section{Research Methodology}

\subsection{Sources of Data}

Secondary data has been used for the study. The annual data for all banks during the financial years of 2006 to 2013 are used for rating the performance of the banks. In addition another source of data was through references to the library and the review if different articles, papers, \& relevant previous studies.

\subsection{Tools and Technique}

Different financial ratios of camels rating have been analyzed for comparing the financial performance of banks.. The study compares the 4 types of bank's time series performance on the basis of selected CAMEL ratios.

\section{Conceptual Framework}

CAMELS ratings are the result of the Uniform Financial Institutions Rating System, the internal rating system used by regulators for assessing financial institutions on a uniform basis and identifying those institutions requiring special supervisory attention. The six key areas of are: adequacy and quality of bank's Capital, Assets (loans and investments), Management, Earnings, Liquidity, and Sensitivity to market risk. It is mentioned here that the rating system had 5(five) components when it was introduced in 1979. The five components were Capital adequacy, Asset quality, Management, Earnings, Liquidity. The sixth component sensitivity to market risk was added in 1996. The regulator that year also added an increased emphasis on an organization's management of risk. Regulator assigns CAMELS ratings both on a component and composite basis, resulting in a single CAMELS overall rating. Thus CAMELS rating system follow two sets of ratings:

1. Each component's key areas individually comprise with numerical point basis. Again the assigned numbers are calculating by given weights which are weighted average of ratio rating. This weighted average of ratio rating treated as performance rating.

2. A comprehensive assessment of the overall condition of the banking company is an overall composite rating.

Further each component of CAMELS is calculated in two ways;

Such as:

1. Weighted average rating and

2. Questionnaire rating which bearing percentage.

It may be calculated as under:

Rating resulting from weighted average of ratio rating

Questionnaire rating

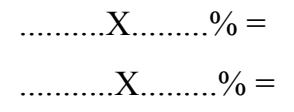

Component ratio

Banks with a rating of 1 are considered most stable; banks with a rating of 2 or 3 are considered average, and those with 
rating of 4 or 5 are considered below average, and are closely monitored to ensure their viability. The ratings range from 1 to 5 , with 1 being the highest rating (representing the least amount of regulatory concern) and 5 being the lowest. CAMELS ratings are strictly confidential, and may not be disclosed to any party.

The following is a description of the gradations to be utilized in assigning performance ratings for the six components:

Rating "1" - Indicates strong performance; (Strong).

Rating "2" - Indicates above average performance that adequately provides for the safe and sound operations of the banking company; (Satisfactory).

Rating " 3 " - Indicates performance that is flawed to some degree. (Fair).

Rating "4" - Indicates unsatisfactory performance. If left unchecked, such performance could threaten the solvency of the banking company. (Marginal).

Rating " 5 " - Indicates very unsatisfactory performance in need of immediate remedial attention for the sake of the banking company's survival. (Unsatisfactory)

\subsection{Capital Adequacy}

Capital adequacy measured by risk based capital ratio (Core capital tier-1- paid up capital, non-repayable share premium, Statutory reserve, General reserve, retained earnings, minority interest in subsidiaries, non-cumulative irredeemable preference share, dividend equalization account. Supplementary capital tier-2- 1\% general provision on unclassified loans, assets revaluation reserves, all other preferences shares, perpetual subordinated debt, exchange equalization account), reserve risk weighted assets and total regulatory capital, off balance sheet items, revaluation reserve to shareholders equity etc.

Previous calculation Process: Avail capital/Required minimum capital X 100 (depended on paid up capital).

Present calculation Process:

Component rating:

Rating resulting from

weighted average of ratio $4.00 \mathrm{X} 0.70=2.80$ rating

Questionnaire rating

$$
\begin{aligned}
& 5.00 \times 0.30=1.50 \\
& \text { Capital adequacy rating }=4.30 \\
& \text { Say total Rating }=4.00
\end{aligned}
$$

\subsection{Asset Quality}

The asset quality measured by classified loans, provision, rescheduled and restructured loans and advances to total loans and advances, concentration to advances to industry, trade, real estate and off balance sheet items etc. Further infrastructure position and environmental situation should be scrutinized by the appropriate authority.

Previous calculation Process: Classified Loans and Advances/Total Loans and Advances

Present calculation Process:

Component rating:
Rating resulting from weighted average of ratio rating

Questionnaire rating

$$
\begin{aligned}
& 4.43 \times 0.70=3.10 \\
& 5.00 \times 0.30=1.50 \\
& \text { Asset Quality rating }=4.60 \\
& \text { Say total Rating }=5.00 \text { (Approx) }
\end{aligned}
$$

\subsection{Management}

Management measured by core risk assessment [Core risks are: Credit Risk Management (CRM), Asset liability Risk Management (ALM), Internal Control and Compliance Risk (ICC), Information and communication technology (ICT), Foreign Exchange Risk Management (Fx), Anti Money laundering (AML)], average rating of $\mathrm{C}, \mathrm{A}, \mathrm{E}, \mathrm{L}$ and $\mathrm{S}$ and questionnaire rating. Again many financing performances of a banking company is rated here like as: SME, Agriculture, Green banking and CSR (Corporate Social Responsibility) etc.

Previous calculation Process: Average of CAMEL means $\mathrm{C}+\mathrm{A}+\mathrm{E}+\mathrm{L} / 4$.

Present calculation Process:

Component rating:

Core Risk Ratings (Average

of core risk ratings)

Average of C, A, E, L and S

$3.37 \times 0.60=2.02$

Questionnaire rating

$$
4.00 \times 0.20=0.80
$$$$
3.00 \times 0.20=.60
$$

Management Rating $=3.42$

Say total Rating $=3.00$

(Approx)

\subsection{Earnings}

Earnings measured by return on assets (ROA), return on equity (ROE), net income margin [(NIM) interest incomeinterest expenses/interest earning assets], total operating expenses and net operating income to total average assets, cash flow, earning power ratio (interest earning assetsinterest bearing liability/interest earning assets), full time employees per branch, staff expenses (salary and allowances including CEO's)

Previous calculation Process: Net Income (after tax)/Total Assets.

Present calculation Process:

Component rating:

Rating resulting from weighted average of ratio rating

Questionnaire rating

$$
\begin{aligned}
& 3.45 \times 0.70=2.42 \\
& 5.00 \times 0.30=1.50 \\
& \text { Earnings Rating }=3.92 \\
& \text { Say total Rating }=4.00 \text { (Approx) }
\end{aligned}
$$

\subsection{Liquidity}

Liquidity measured by cash reserve ratio (CRR), statutory liquidity requirement (SLR), liquidity coverage ratio (LCR), term deposit, volatile liabilities, liquid able assets, call money market activities, off balance sheet items to stock of high 
quality liquid assets etc. Further infrastructure position and environmental situation should be scrutinized by the appropriate authority. Vault safety can be included in liquidity component rating to improve quality of liquidity part of CAMELS.

Previous calculation Process: Available position of (a) CRR+SLR, (b) Deposit with BB and others bank, (c) Available position of government securities those held to maturity and held for trading. The government securities are Treasury bond, Treasury bill, Prize bond and others easily liquid able assets, (d) Profitability.

Present calculation Process:

Component rating:

Rating resulting from weighted average of ratio rating

Questionnaire rating

$$
\begin{aligned}
& 3.00 \times 0.75=2.25 \\
& 3.00 \times 0.25=0.75
\end{aligned}
$$

Liquidity Rating $=3.00$

\subsection{Sensitivity to Market Risk}

Sensitivity measured by post shock core income (interest rate risk), loss in capital market investment (increased provision due to share price drop), net open foreign exchange position to regulatory capital (foreign exchange risk), and equity risk etc.

Component rating:

Rating resulting from weighted average of ratio rating

Questionnaire rating

$$
3.67 \times 0.70=2.57
$$

$$
4.00 \times 0.30=1.20
$$

Sensitivity to Market Risk

Rating $=3.77$

Say total Rating $=4.00$ (Approx)

\subsection{Composite Ratings}

In assigning a composite rating for a banking company, consideration must be given to the individual component ratings of the CAMELS. These components can be weighted and summed, as shown in TABLE-1, In order to quantify a composite rating. However, a composite estimate may need modification as a result of qualitative factors that may influence the inspectors' overall opinion of the condition and performance of the bank.

Composite ratings may be distinguished as follows:

Composite-1 (Strong) Banking companies in this group are basically sound in every respect. Any deficiencies are minor and can be handled in a routine manner by the banking company

Such a banking company is resistant to outside economic and financial disturbances and, as a result, gives no cause for supervisory concern.

Composite-2 (Satisfactory) Banking companies in this group are fundamentally sound, but may demonstrate modest weakness that is easily correctable. To the extent that remedial modifications could be handled in the normal course of the banking company's business, supervisory concern would be minor.

Composite-3 (Fair) - Banking companies in this category exhibit a combination of financial, operational and compliance weaknesses ranging from moderately severe to unsatisfactory. Such banking companies may be vulnerable to the onset of adverse business conditions and could be easily deteriorate if concerted action is not taken to correct the areas of weakness. Banking companies that exhibit significant instances of non-compliances with legislation and regulations may also be accorded this rating. Consequently, these banking companies give cause for supervisory concern and require more than normal supervision to address deficiencies. The overall strength and financial capacity of these institutions, however, are still such as to make failure only a remote possibility.

Composite-4 (Marginal) - Banking companies in this group have a number of serious financial or operational weakness. Unless effective action is taken to correct these conditions, they could easily escalate into a situation that could impair future solvency. Banking companies in this category require close supervisory attention and a definitive plan for corrective action.

Composite-5 (Unsatisfactory) - This category is reserved for those banking companies which are in dire need of assistance or even takeover by BB. The volume and severity of the unsafe and unsound conditions are such as to require a major recapitalization effort. In the absence of decisive corrective measures, these situations would likely require BB financial support or take over.

Previous calculation Process: $\mathrm{C}+\mathrm{A}+\mathrm{M}+\mathrm{E}+\mathrm{L} / 5=$ Composite Rating

Present calculation Process:

Composite Rating:

Composite rating shall be measure by multiplying in the ratings pertaining to $\mathrm{C}, \mathrm{A}, \mathrm{M}, \mathrm{E}, \mathrm{L}$ and $\mathrm{S}$ with the weight as depicted below:

Table 1. Composite Rating.

\begin{tabular}{lllll}
\hline $\begin{array}{l}\text { Serial } \\
\text { No. }\end{array}$ & Component & Ratings & Weight & $\begin{array}{l}\text { Weighted } \\
\text { Ratings (WR) }\end{array}$ \\
\hline 1. & Capital Adequacy (C) & 4.00 & 0.20 & 0.80 \\
\hline 2. & Assets Quality(A) & 5.00 & 0.20 & 1.00 \\
3. & Management (M) & 3.00 & 0.25 & 0.75 \\
4. & Earnings(E) & 4.00 & 0.15 & 0.60 \\
5. & Liquidity(L) & 3.00 & 0.10 & 0.30 \\
6. & Sensitivity to Market & 4.00 & 0.10 & 0.40 \\
\hline & Risk(S) & & 1.00 & 3.85 \\
\hline
\end{tabular}

Say Total Composite Rating $=4.00$ (Approx).

Composite Rating $=4.00$ means Marginal.

\section{Discussion and Analysis}

Table 2 shows that on 31 December 2013, in aggregate, the SCBs, DFIs, PCBs and FCBs maintained CAR of 10.8, -9.7, 12.6, and 20.2 percent respectively. But individually, 2 SCBs, 
2 PCBs, 1 FCB and 3 DFIs did not maintain the minimum required $\mathrm{CAR}$. The CAR of the banking industry as a whole was 11.5 percent at end of December 2013 as against 10.5 percent at the end of 2012. Implementation of new revised policy on loan rescheduling (BRPD Circular no. 15/2013) was the main reason of increase in CAR in 2013. On the other hand, increase of classified loans resulted in rise of deficit of capital of 2 SCBs (Sonali, Rupali), 3 DFIs (BKB, BASIC, RAKUB), 2 PCBs (BCBL, ICB Islamic) and 1 FCB (NBP). The CAR of the industry was 10.7 percent at end of June 2014.

Table 2. Capital to risk weighted assets ratio by types of bank (Percent).

\begin{tabular}{lllllllll}
\hline $\begin{array}{l}\text { Bank } \\
\text { types }\end{array}$ & $\mathbf{2 0 0 6}$ & $\mathbf{2 0 0 7}$ & $\mathbf{2 0 0 8}$ & $\mathbf{2 0 0 9}$ & $\mathbf{2 0 1 0}$ & $\mathbf{2 0 1 1}$ & $\mathbf{2 0 1 2}$ & $\mathbf{2 0 1 3}$ \\
\hline SCBs & 1.1 & 7.9 & 6.9 & 9.0 & 8.9 & 11.7 & 8.1 & 10.8 \\
DFIs & -6.7 & -5.5 & -5.3 & 0.4 & -7.3 & -4.5 & -7.8 & -9.7 \\
PCBs & 9.8 & 10.6 & 11.4 & 12.1 & 10.1 & 11.5 & 11.4 & 12.6 \\
FCBs & 22.7 & 22.7 & 24.0 & 28.1 & 15.6 & 21.0 & 20.6 & 20.2 \\
Total & 6.7 & 9.6 & 10.1 & 11.6 & 9.3 & 11.4 & 10.5 & 11.5 \\
\hline
\end{tabular}

Source: Bangladesh Bank Annual Report.

Table 3. NPL ratios by types of bank (Percent).

\begin{tabular}{lllllllll}
\hline $\begin{array}{l}\text { Bank } \\
\text { types }\end{array}$ & $\mathbf{2 0 0 6}$ & $\mathbf{2 0 0 7}$ & $\mathbf{2 0 0 8}$ & $\mathbf{2 0 0 9}$ & $\mathbf{2 0 1 0}$ & $\mathbf{2 0 1 1}$ & $\mathbf{2 0 1 2}$ & $\begin{array}{c}\mathbf{2 0 1 3} \\
\text { June }\end{array}$ \\
\hline SCBs & 22.9 & 29.9 & 25.4 & 21.4 & 15.7 & 11.3 & 23.9 & 19.8 \\
DFIs & 33.7 & 28.6 & 25.5 & 25.9 & 24.2 & 24.6 & 26.8 & 26.8 \\
PCBs & 5.5 & 5.0 & 4.4 & 3.9 & 3.2 & 2.9 & 4.6 & 4.5 \\
FCBs & 0.8 & 1.4 & 1.9 & 2.3 & 3.0 & 3.0 & 3.5 & 5.5 \\
Total & 13.2 & 13.2 & 10.8 & 9.2 & 7.3 & 6.1 & 10.0 & 8.9 \\
\hline
\end{tabular}

Source: Bangladesh Bank Annual Report.

The ratio of NPL to total loans of all the banks had shown an overall declining trend from its peak (34.9 percent) in 2000 up to 2011 (6.1 percent). But the ratio increased in 2012 (10.0 percent), decreased again in 2013 (8.9 percent), then increased (10.8 percent) at end June 2014. NPLs to total loans ratio in recent years till 2011 can be attributed partly to some progress in recovery of long outstanding loans and partly to write-off of loans classified as 'bad' or 'loss'. But it went up again in 2012 \& 2014 (end June) due to the reasons of issuance of the circular regarding new classification and rescheduling of loans and a few notable scams in the banking industry.

The SCBs and DFIs continue to have high level of NPLs mainly due to substantial loans provided by them on considerations other than commercial criteria. Furthermore, these banks were reluctant to write-off the historically accumulated bad loans because of poor quality of underlying collaterals. Recovery of NPLs, however, has showed some signs of improvement, mainly because of the steps taken with regard to internal restructuring of these banks to strengthen their loan recovery mechanism and write-off measures initiated in recent years.

Table 4. Ratio of net NPL to total loans by types of bank (Percent).

\begin{tabular}{lllllllll}
\hline $\begin{array}{l}\text { Bank } \\
\text { types }\end{array}$ & $\mathbf{2 0 0 6}$ & $\mathbf{2 0 0 7}$ & $\mathbf{2 0 0 8}$ & $\mathbf{2 0 0 9}$ & $\mathbf{2 0 1 0}$ & $\mathbf{2 0 1 1}$ & $\mathbf{2 0 1 2}$ & $\begin{array}{l}\mathbf{2 0 1 3} \\
\text { June }\end{array}$ \\
\hline SCBs & 14.5 & 12.9 & 5.9 & 1.9 & 1.9 & -0.3 & 12.8 & 1.7 \\
DFIs & 23.6 & 19.0 & 17.0 & 18.3 & 16.0 & 17.0 & 20.4 & 19.7 \\
PCBs & 1.8 & 1.4 & 0.9 & 0.5 & 0.0 & 0.2 & 0.9 & 0.6 \\
FCBs & -2.6 & -1.9 & -2.0 & -2.3 & -1.7 & -1.8 & -0.9 & -0.4 \\
Total & 7.1 & 5.1 & 2.8 & 1.7 & 1.3 & 0.7 & 4.4 & 2.0 \\
\hline
\end{tabular}

Source: Bangladesh Bank Annual Report.

Table 4 shows that in 2013, the ratio of net NPLs (net of provisions and interest suspense) to net total loans (net of provisions and interest suspense) was 2.0 percent for the banking sector and 19.7 percent for DFIs. It is revealed in the table that DFIs' nonperforming portfolios were still high after adjustment of actual provision and interest suspense, whereas SCBs, FCBs and PCBs had excess provision against their NPLs. The net NPLs to net total loan ratios were 1.7, 0.6, and -0.4 percent for the SCBs, PCBs and FCBs respectively at the end of December 2013. The ratios were 7.4, 26.4, 1.2 and 0.2 percent for SCBs, DFIs, PCBs and FCBs at the end June 2014.

Table 5. Amounts of NPLs (Billion taka).

\begin{tabular}{|c|c|c|c|c|c|c|c|c|c|}
\hline Bank types & 2005 & 2006 & 2007 & 2008 & 2009 & 2010 & 2011 & 2012 & 2013 June \\
\hline SCBs & 100.2 & 115.0 & 137.9 & 127.6 & 117.5 & 107.6 & 91.7 & 215.2 & 166.1 \\
\hline DIFs & 38.4 & 41.5 & 37.2 & 37.3 & 42.1 & 49.7 & 56.5 & 73.3 & 83.6 \\
\hline PCBs & 35.5 & 43.7 & 49.2 & 57.0 & 61.7 & 64.3 & 72.0 & 130.4 & 143.1 \\
\hline FCBs & 1.0 & 0.8 & 1.9 & 2.9 & 3.5 & 5.5 & 6.3 & 8.5 & 13.0 \\
\hline Total & 175.0 & 201.0 & 226.2 & 224.8 & 224.8 & 227.1 & 226.5 & 427.3 & 405.8 \\
\hline
\end{tabular}

Source: Bangladesh Bank Annual Report.

Table 5 displays the amount of NPLs of the 4 type of banks since 2006 to 2014 (end June). The amount of NPLs of the SCBs increased from Taka 115.0 billion in 2006 to Taka 166.1 billion in 2013. The PCBs recorded a total increase of Taka 99.4 billion in their NPL accounts, which stood at Taka 143.1 billion in 2013 as against Taka 43.7 billion in 2006 .
The amount of NPLs of the DFIs increased to Taka 83.6 billion in 2013 from Taka 41.5 billion in 2006. The amount of NPLs of the FCBs increased from Taka 0.8 billion in 2006 to Taka 13.0 billion in 2013. The amount of NPLs of SCBs, DFIs, PCBs and FCBs stood at Taka 197.2, 110.5, 191.5 and 14.2 billion respectively at the end of June 2014. 
Table 6. Required provision and provision maintained-all Banks (Percent).

\begin{tabular}{|c|c|c|c|c|c|c|c|c|c|}
\hline ALL banks & 2005 & 2006 & 2007 & 2008 & 2009 & 2010 & 2011 & 2012 & 2013 June \\
\hline amount of NPLs & 175.1 & 200.1 & 226.2 & 224.8 & 224.8 & 227.1 & 226.4 & 427.3 & 405.8 \\
\hline Required provision & 88.3 & 106.1 & 127.2 & 136.1 & 134.8 & 149.2 & 148.2 & 242.4 & 252.4 \\
\hline Provision maintained & 42.6 & 52.9 & 97.1 & 126.2 & 137.9 & 142.3 & 152.7 & 189.8 & 249.8 \\
\hline \multirow[t]{2}{*}{ Excess $(+)$ shortfall(-) } & -45.7 & -53.2 & -30.1 & -9.9 & 3.1 & -6.9 & 4.6 & -52.6 & -2.6 \\
\hline & 48.2 & 49.9 & 76.3 & 92.7 & 102.3 & 95.4 & 103.04 & 78.3 & 99.0 \\
\hline
\end{tabular}

Source: Bangladesh Bank Annual Report.

Table 6 shows the aggregate amount of NPLs, the required loan loss provision and the actual provision maintained by the banks from 2006 to end June 2014. It depicts that in aggregate, the banks have been continuously failing to maintain the required level of provisions against their NPLs from 2006 to 2013 except the year 2009 and 2011. Table shows that in 2009 and 2011, the banking sector was able to maintain 100 percent or more of the required provisions. Banks maintained 49.9 percent of the required provision in 2006; which increased thereafter to 103.0 percent in 2011, then declined to 99.0 percent in 2013 and to 86.7 percent at end of June 2014.

Table 7. Comparative position of provision adequacy (Billion taka).

\begin{tabular}{|c|c|c|c|c|c|}
\hline year & Items & SCBs & SBs & PCBs & FCBs \\
\hline \multirow{3}{*}{2011} & Required provision & 60.8 & 21.7 & 58.3 & 7.4 \\
\hline & Provision maintained & 69.0 & 13.9 & 61.2 & 8.5 \\
\hline & Provision maintenance ratios & 113.5 & 64.1 & 105.0 & 114.3 \\
\hline \multirow{3}{*}{2012} & Required provision & 119.2 & 29.8 & 84.4 & 8.9 \\
\hline & Provision maintained & 81.9 & 13.6 & 84.9 & 9.3 \\
\hline & Provision maintenance ratios & 68.7 & 45.7 & 100.6 & 104.3 \\
\hline \multirow{3}{*}{2013 June } & Required provision & 107.8 & 38.3 & 94.8 & 11.6 \\
\hline & Provision maintained & 122.3 & 17.4 & 97.8 & 12.3 \\
\hline & Provision maintenance ratios & 113.5 & 45.5 & 103.2 & 106.0 \\
\hline
\end{tabular}

Source: Bangladesh Bank Annual Report.

The main reason for the shortfall in provision adequacy from 2000 to 2013 was the inability of some SCBs, DFIs and PCBs, including those in the problem bank category to make sufficient provisions due to inadequate profits and provision transfer for write-offs. Notably, the FCBs are in a much better position; as they have been able to make adequate provisions during the period under consideration. A comparative position of loan loss provisions as of end 2012, 2013 and 2014 (end June) is shown in Table 7

Table 8. Writing off bad debt on different bank categories (Billion taka).

\begin{tabular}{|c|c|c|c|c|c|c|c|}
\hline Bank types & 30 june 07 & 30 june 08 & 30 june 09 & 30 june 10 & 30 june 11 & 30 june 12 & 30 june 13 \\
\hline SCBs & 42.8 & 48.4 & 64.5 & 70.5 & 82.4 & 72.9 & 107.2 \\
\hline DFIs & 30.4 & 31.0 & 31.8 & 31.8 & 32.0 & 24.5 & 32.6 \\
\hline PCBs & 45.5 & 49.4 & 54.7 & 69.6 & 77.1 & 64.9 & 109.7 \\
\hline FCBs & 1.6 & 1.7 & 2.0 & 2.1 & 2.4 & 2.6 & 4.4 \\
\hline Total & 120.3 & 130.5 & 153.0 & 174.0 & 193.9 & 164.9 & 253.3 \\
\hline
\end{tabular}

Source: Bangladesh Bank Annual Report.

To correct an unnecessarily and artificially inflated size of the balance sheet, uniform guidelines for write-offs were introduced in 2003. According to the policy, banks may, at any time, classify write-off loans as bad/loss. Those loans, which have been classified as bad/loss for the last 5 years and above and loans for which 100 percent provisions have been kept, should be written off immediately. The total amount of written- off bad debts from June 2007 to June 2014 in different bank categories is given in Table 8 .

Table 9. Expenditure-income ratio by types of bank (Percent).

\begin{tabular}{|c|c|c|c|c|c|c|c|c|c|c|}
\hline Bank types & 2004 & 2005 & 2006 & 2007 & 2008 & 2009 & 2010 & 2011 & 2012 & 2013 June \\
\hline SCBs & 102.3 & 101.9 & 100.0 & 100.0 & 89.6 & 75.6 & 80.7 & 62.7 & 73.2 & 84.1 \\
\hline DFIs & 104.0 & 103.9 & 103.0 & 107.7 & 103.7 & 112.1 & 87.8 & 88.6 & 91.2 & 94.8 \\
\hline PCBs & 87.1 & 89.3 & 90.2 & 88.8 & 88.4 & 72.6 & 71.7 & 71.7 & 76.0 & 77.9 \\
\hline Total & 90.9 & 92.1 & 91.4 & 90.4 & 87.9 & 72.6 & 68.6 & 68.8 & 74.0 & 77.8 \\
\hline
\end{tabular}

Source: Bangladesh Bank Annual Report. 
Sound management is the most important and inescapable pre-requisite for the strength and concrete growth of any financial institution. It is difficult to draw any conclusion regarding management soundness based on quantitative indicators, as characteristics of a good management are rather qualitative in nature. Nevertheless, the total expenditure to total income, operating expenses to total expenses, earnings and operating expenses per employee, and interest rate spread are generally used to portray management soundness. Technical competence \& leadership of mid and senior level management, compliance to plan and respond to changing circumstances, etc are also taken into consideration in evaluating the quality of management.

As evident from Table 9, in 2013, the expenditure-income (EI) ratio of the DFIs was the highest among the displayed bank clusters. The EI ratio of the SCBs was 84.1 in 2013, the second highest, which could mainly be attributable to high administrative and operating expenses. The EI ratio of SCBs increased from 73.2 percent in 2012 to 84.1 percent in 2013. The EI ratio of SCBs, PCBs, FCBs declined to 83.3, 75.8, 46.5 percent respectively and rose to 112.0 percent for DFIs at end June 2014. stances, etc., are also taken into consideration in evaluating the quality of management.

Table 10. Profitability ratios by types of bank (Percent).

\begin{tabular}{|c|c|c|c|c|c|c|c|c|c|c|c|c|c|c|c|c|}
\hline \multirow[t]{2}{*}{$\begin{array}{l}\text { Bank } \\
\text { types }\end{array}$} & \multicolumn{6}{|c|}{$\begin{array}{l}\text { Returns on } \\
\text { assets (ROA) }\end{array}$} & \multirow[b]{2}{*}{2012} & \multirow[b]{2}{*}{2013 June } & \multirow[b]{2}{*}{2006} & \multirow[b]{2}{*}{2007} & \multicolumn{2}{|c|}{$\begin{array}{l}\text { Return on } \\
\text { equity (ROE) }\end{array}$} & \multirow[b]{2}{*}{2010} & \multirow[b]{2}{*}{2011} & \multirow[b]{2}{*}{2012} & \multirow[b]{2}{*}{2013 June } \\
\hline & 2006 & 2007 & 2008 & 2009 & 2010 & 2011 & & & & & 2008 & 2009 & & & & \\
\hline SCBs & 0.0 & 0.0 & 0.7 & 1.1 & 1.1 & 1.3 & -0.6 & 0.6 & 0.0 & 0.0 & 22.5 & 26.2 & 18.4 & -11.9 & 109.5 & -2.4 \\
\hline DFIs & -0.2 & -0.3 & -0.6 & 0.4 & 0.2 & 0.1 & 0.1 & -0.4 & -2.0 & -3.4 & -6.9 & -171.7 & -3.2 & -1.1 & 5.8 & -9.5 \\
\hline PCBs & 1.1 & 1.3 & 1.4 & 1.6 & 2.1 & 0.9 & 0.9 & 1.0 & 15.2 & 16.7 & 16.4 & 21.0 & 20.9 & 10.2 & 9.8 & 8.4 \\
\hline FCBs & 2.2 & 3.1 & 2.9 & 3.2 & 2.9 & 3.3 & 3.3 & 3.0 & 21.5 & 20.4 & 17.8 & 22.4 & 17.0 & 17.3 & 16.9 & 20.1 \\
\hline Total & 0.8 & 0.1 & 1.2 & 1.4 & 1.8 & 0.6 & 0.6 & 0.9 & 14.1 & 13.8 & 15.6 & 21.7 & 21.0 & 8.2 & 11.0 & 8.4 \\
\hline
\end{tabular}

Source: Bangladesh Bank Annual Report.

There are various indicators of earnings and profitability but the most representative and widely used one is Return on Assets (ROA), which is supplemented by Return on Equity (ROE) and Net Interest Margin (NIM).

Earnings as measured by Return on Assets (ROA) and Return on Equity (ROE) differ greatly within the industry. Table 10 shows ROA and ROE by type of banks.

Analysis of these indicators reveals that the ROA of the SCBs was less than the industry average. The ROA of SCBs was gradually increasing up to 2011 , but it dropped down to negative ( 0.6 percent) in 2012 due to a huge net loss in the year. In 2013, it increased and became positive. The DFIs' situation is not getting better due to persistent operating losses incurred by BKB and RAKUB. The ROA of DFIs' deteriorated more scoring negative ( 0.4 percent) in 2013. PCBs' ROA showed a consistently strong position up to 2010, but it was in a decreasing trend during 2011 and 2012 due to decrease of net profit. In 2013, it didn't drop from the previous year. Though FCBs' ROA had been consistently strong during the last couple of years, it decreased slightly in 2013 and again increased in June 2014.

SCBs' ROE shows a sign of positive indication in 2013 through an increased rate of 10.9 percent whereas it dropped to 11.9 percent (negative) in 2012 due to an increased amount of provisioning required against an increased amount of NPLs. In case of DFIs, the ROE was positive in 2013 which was negative for the last couple of years. The ROE of PCBs was robust up to 2010. It was on decreasing trend for previous couple of years; it was 9.8 percent in 2013 against 15.7 percent in 2011 . It declined to 8.4 percent at end June 2014. The ROE of FCBs shows steady fluctuation throughout some of the previous years. The ROE of FCBs in 2010 stood at 17.0 percent, which fell to 16.9 percent in 2013 and rose to
20.1 percent at end June 2014.

Table 11. Net interest income by types of bank (Billion taka).

\begin{tabular}{lllllllll}
\hline $\begin{array}{l}\text { Bank } \\
\text { types }\end{array}$ & $\mathbf{2 0 0 6}$ & $\mathbf{2 0 0 7}$ & $\mathbf{2 0 0 8}$ & $\mathbf{2 0 0 9}$ & $\mathbf{2 0 1 0}$ & $\mathbf{2 0 1 1}$ & $\mathbf{2 0 1 2}$ & $\begin{array}{l}\mathbf{2 0 1 3} \\
\text { June }\end{array}$ \\
\hline SCBs & 9.0 & 7.4 & 7.9 & 12.1 & 19.8 & 34.3 & 14.9 & -5.4 \\
DFIs & 1.7 & 1.4 & 1.9 & 1.9 & 6.2 & 4.9 & 4.7 & 3.8 \\
PCBs & 25.4 & 36.1 & 48.5 & 56.7 & 82.8 & 91.4 & 114.7 & 118.2 \\
FCBs & 8.2 & 9.9 & 12.6 & 10.7 & 13.0 & 16.1 & 19.6 & 15.8 \\
Total & 44.3 & 54.8 & 70.9 & 81.5 & 121.9 & 146.7 & 153.8 & 132.3 \\
\hline
\end{tabular}

Source: Bangladesh Bank Annual Report.

Aggregate net interest income (NII) of the industry had consistently increased from Taka 44.3 billion in 2006 to Taka 153.8 billion in 2012. But in 2013, aggregate NII of the industry fell down to Taka 132.3 billion reflected mainly in the negative NII of Taka 5.4 billion by the SCBs. The NII of the PCBs showed gradual increasing trend from 2006 to 2013 whereas NII of DFIs and FCBs were fluctuating in stable condition. The decline in net interest income during the year is attributed to the shifting of investment funds from loans and advances to investments in liquid assets.

Since 2006, SCBs have been able to increase their net interest income (NII) by reducing their cost of funds up to 2011. In 2012, the NII of SCBs dropped and alarming situation occurred in 2013 due to higher interest expenses which grew faster than interest earnings. The NII of the PCBs had been significantly high during the span of time from 2006 to 2013. Overall industry NII showed a consistently upward trend from 2006 to 2012 though it went reverse in 2013 due to the lackluster performance of SCBs. The trend of NII indicates that the interest spreads of PCBs and FCBs were higher than that of SCBs and DFIs. The NII of different categories of bank declined at the end of June 2014. 
Table 12. Liquidity ratios by types of banks (Percent).

\begin{tabular}{|c|c|c|c|c|c|c|c|c|c|c|c|c|c|c|c|c|}
\hline Bank types & & & Liqui & sets & & & & & & & Exces & assets & & & & \\
\hline & 2006 & 2007 & 2008 & 2009 & 2010 & 2011 & 2012 & $\begin{array}{l}2013 \\
\text { june }\end{array}$ & 2006 & 2007 & 2008 & 2009 & 2010 & 2011 & 2012 & $\begin{array}{l}2013 \\
\text { June } \\
\end{array}$ \\
\hline SCBs & 20.1 & 24.9 & 32.9 & 25.1 & 27.2 & 31.3 & 29.2 & 44.3 & 2,1 & 6.9 & 14.9 & 17.6 & 8.2 & 12.3 & 10.2 & 25.3 \\
\hline DFIs & 11.9 & 14.2 & 13.7 & 9.6 & 21.3 & 6.9 & 11.5 & 15.3 & 3.8 & 5.6 & 4.9 & 7.1 & 2.3 & 1.3 & 1.4 & 1.2 \\
\hline PCBs & 21.4 & 22.2 & 20.7 & 18.2 & 21.5 & 23.5 & 26.3 & 28.0 & 5.6 & 6.4 & 4.7 & 5.3 & 4.6 & 6.6 & 9.5 & 12.8 \\
\hline FCBs & 34.4 & 29.2 & 31.3 & 31.8 & 32.1 & 34.1 & 37.5 & 46.2 & 16.4 & 11.2 & 13.3 & 21.8 & 13.2 & 15.3 & 18.7 & 34.9 \\
\hline Total & 21.5 & 23.2 & 24.8 & 20.6 & 23.0 & 25.4 & 27.1 & 32.5 & 5.1 & 6.9 & 8.4 & 9.0 & 6.0 & 8.4 & 9.9 & 17.3 \\
\hline
\end{tabular}

Source: Bangladesh Bank Annual Report.

Currently the scheduled commercial banks have to maintain a CRR (Cash Reserve Ratio) averaging 6.5 percent daily on bi-weekly basis against Average Total Demand and Time Liabilities (ATDTL) of the preceding 2nd of the month, with an obligation to maintain daily minimum 6 percent cash against the same ATDTL held by the bank. The current rate of SLR (Statutory Liquidity Reserve) for conventional banks is 13 percent of time and demand liabilities. In case of Islamic shariah-based commercial banks, the rate of SLR is 5.5 percent of their total time and demand liabilities. The specialized banks (except Basic Bank Ltd.) are exempted from maintenance of SLR, but they have to maintain the CRR at the stated rate. The banks maintain CRR in cash with Bangladesh Bank. However, they are allowed to hold Government approved securities (unencumbered portion) for maintenance of the SLR.

Table 12 shows that the FCBs had the highest liquidity ratios followed by the SCBs. There was an increasing trend in the percentage of liquid assets in total assets of the banks during the last four years.

\section{Conclusion}

It can be understandable that our banking sector is a major industry in our emerging economy. We should look after and nursing very carefully this sector which may be developed and expanded its activities in all respect. Very virtually it is said that the economy of a country depends on its banking system. As banking system be healthy, as well as country's economy be healthy and wealthy. So banking system should monitor very cautiously. The assessing instrument is CAMELS. From the study, it can be said that $2 \mathrm{SCBs}, 2 \mathrm{PCBs}, 1 \mathrm{FCB}$ and 3 DFIs did not maintain the minimum required CAR. The SCBs and DFIs continue to have high level of NPLs mainly due to substantial loans provided by them on considerations other than commercial criteria. The banks have been continuously failing to maintain the required level of provisions against their NPLs from 2006 to 2013 except the year 2009 and 2011. The FCBs had the highest liquidity ratios followed by the SCBs. There was an increasing trend in the percentage of liquid assets.

\section{References}

[1] Bangladesh Bank Annual Report, (2006-2014), (www.bangladesh-bank.org) Bangladesh Bank Manual for Ratio Analysis and CAMEL Rating System (2006), $\mathrm{http} / /$ ncalculators.com/statistics/correlation-coefficientcalculator.htm.

[2] C, D, Parimal. K, G, Badal. Hasan Tuhin, Mehedi Financial Performance in Banking Sector in Bangladesh: A Comparative Study of Some Selected Private Commercial Banks. Journal of Banking \& Financial Services, Department of Banking Faculty of Business Studies University of Dhaka. Vol. 5 Number 1 July 2011.

[3] Chowdhury, T. A., \& Ahmed, K. (2009), "Performance Evaluation of Selected Commercial Banks in Bangladesh", International Journal of Business and Management, 4(4), 86-97.

[4] Khan, A. R. (2009), "Sources and uses of funds, performance evaluation and bank failure", Bank Management: A fund Emphasis, (2nd edition), Dhaka: Decent Book House, pp. 5168 .

[5] CHIEN, T., DANW, S. Z. (2004), "Performance Measurement of Taiwan Commercial Banks", International Journal of Productivity and Performance Management, Vol. 53(5), pp. 425-434.

[6] MAZER, M., ISLAN (2003), "Development and Performance of Domestic and Foreign Banks in GCC Countries", Managerial Finance, Vol. 29(2), pp. 42-71.

[7] MEDHAT, T. (2006), “A Comparison of Financial Performance in the Banking Sector: Some Evidence from Oman Commercial Banks", http://www.eurojournals.com

[8] Cole, R. A., and J. W. Gunther. (1998). "Predicting Bank Failures: A Comparison of On- and Off-Site Monitoring Systems." Journal of Financial Services Research 13, pp. 103117.

[9] Reserve Bank of India, (2008) Efficiency, Productivity and Soundness of the Banking Sector, p.401, 419. http://rbi.org.in/scripts/publicationsview.aspx?id=10496 50 .

[10] Alam, Hassan Mobeen, Raza, Ali \& Akram, Muhammad, 2011. A Financial Performance Comparison of Public Vs Private Banks: The Case of Commercial Banking Sector of Pakistan', International Journal of Business and Social Science, vol. 2, no. 11, pp. 56-64. 
[11] Baral, JK, 2005. Health Check-up of Commercial Banks in the Framework of CAMEL: A Case Study of Joint Venture Banks in Nepal', Journal of Nepalese Business Studies, vol. 2, no. 1, pp. 41-55.

[12] Bodla, BS \& Verma, R., 2006. Evaluating Performance of Banks through CAMEL Model: A Case Study of SBI and ICICI', The ICFAI Journal of Bank Management, vol. 5, no. 3, pp. 49-63.

[13] Christopoulos, AG, Mylonakis, J \& Diktapanidis, P., 2011. Could Lehman Brothers Collapse be Anticipated? An Examination Using CAMELS Rating System', International Business Research, vol. 4, no. 2, pp. 11-19.

[14] Dahiyat, Ahmed., 2012. The Application of CAMELS Rating System to Jordanian Brokerage Firms', International Research Journal of Finance and Economics, vol. 88, pp. 16-23.

[15] Dang, Uyen, 2011. The CAMEL Rating System in Banking
Supervision a Case Study, Dissertation, Arcada University of Applied Science, International Business, viewed 1 August 2014, <http://www.studymode.com/essays/Camel-Rating-InBanking-1737636.html>.

[16] Gupta, R. \& Kaur, S., 2008. A CAMEL Model Analysis of Private Sector Banks in India', Journal of Gyan Management, vol. 2, no. 1, pp. 3-8.

[17] Padmanabhan Working Group, 1995. On-site Supervision of Banks', Reserve Bank of India. Sangmi, M, Tabassum, N., 2010. Analyzing Financial Performance of Commercial Banks in ndia: Application of CAMEL Model', Pakistan Journal Commercial Social Sciences, vol. 4, no. 1, pp. 40-55.

[18] Sarker, A., 2005. CAMEL Rating System in the Context of Islamic Banking: A Proposed 'S'for Shariah Framework', Journal of Islamic Economics and Finance, vol. 1, no. 1, pp. 78-84. 